\title{
Modelling Theory of Planned Behavior on Health Concern and Health Knowledge towards Purchase Intention on Organic Products
}

\author{
Chomsaeank Photcharoen ${ }^{1}$, Rebecca Chung ${ }^{1} \&$ Raksmey Sann ${ }^{1,2}$ \\ ${ }^{1}$ Department of Tropical Agriculture and International Cooperation, National Pingtung University of Science and \\ Technology, Pingtung, Taiwan \\ ${ }^{2}$ Tourism Management Division, International College, Khon Kaen University, Khon Kaen 40002, Thailand \\ Correspondence: Rebecca Chung, Department of Tropical Agriculture and International Cooperation, National \\ Pingtung University of Science and Technology, 1 Shuefu Road, Neipu, Pingtung 91201, Taiwan.
}

Received: June 1, 2020

Accepted: July 9, 2020

Online Published: July 22, 2020

doi:10.5539/ibr.v13n8p100

URL: https://doi.org/10.5539/ibr.v13n8p100

\begin{abstract}
Organic products have been gaining popularity among consumers worldwide due to the environmental and health benefits they are associated with. As a result of this trend, organic industries have been flourishing and have been able to expand into a variety of consumer product/service categories. Looking to explore purchasing behavior related organic coconut cosmetic products, this study attempted to apply the theory of planned behavior (TPB), which is a method of predicting consumer behavior that has been used extensively in a variety of research areas in recent years. Based upon the literature review, an extended TPB model that incorporates health concerns and health knowledge, in addition to attitude, subjective norms and perceived behavior control was examined in this study. For the data collection, an online survey was issued to residents of Bangkok, Thailand; with a total of 613 respondents retuning the questionnaires. Structural equation modeling (SEM) was employed to analyze the data using SPSS AMOS 24. The results showed that attitude, subjective norms, perceived behavior control and health concerns positively affect purchase intention; however, health knowledge did not influence purchase intentions related to the organic coconut cosmetic products. Similar to the findings in most extant literature, attitude was found to exert the most influence on the purchase behavior in this study.
\end{abstract}

Keywords: organic coconut, health concern, health knowledge, behavior intention

\section{Introduction}

Public concern regarding environmental issues has been growing progressively (Kirk, 1995; Laroche, Bergeron, \& Barbaro-Forleo, 2001). Consumers are aware that their purchasing behavior might have direct or indirect adverse impacts on the environment. Consequently, consumers are modifying their purchasing behavior, and gravitating towards products perceived to be environmentally friendly. Therefore, the rising "green consumerism", which entails the production, promotion, and advancement of goods and services that are understood to have more positive impacts on the environment (Akenji, 2014), is now having a considerable influence on the decisions being made in various business segments, and is modifying manufacturing processes and operational procedures (D'Souza \& Taghian, 2005). The term "green", in these contexts, is well understood to have such connotations as "eco-friendly", "environmentally friendly", or "sustainable" (Kim et al., 2013). Within the world of green consumerism, organic products play a central role. Evidence for this can be seen, in part, by the positive growth that pushed global sales in the organic market up to 97 billion US dollars in 2017. In terms of market share, organic food sales in America accounted for the most (valued at 48.7 billion US dollars), follow by Europe (valued at 39.6 billion US dollars), and then the rest of the world (with a combined value of 8.7 billion US dollars) (Willer \& Lernoud, 2019). This suggests that, as the idea spreads, organic product markets will continue to experience correspondent growth.

For instance, nowadays Thai consumers are more concerned about health and environment related problems than they were in the past. These concerns are inspiring them to search for higher-quality and healthier products, preferably without chemical substances. Meanwhile, according to a report from the United Nations Food and Agriculture Organization (FAO, 2016), Thailand is importing about THB 30,000 million of agriculture chemicals per year, and ranked $4^{\text {th }}$ in the world for insecticide use. For this reason, cancer risk among farmers is higher than it is among those in other vocations (Ueausangkomsate \& Santiteerakul, 2016). Related concerns have been 
fostering growth in Thailand's organic agriculture market for a number of years now, and the trend is likely to continue. With growing demand for greater variety in organic products, some believed that in the future, the organic industry will develop into the largest health-oriented market in the world (Leong \& Ng, 2014). Even now, there are a great number of different types of organic products available; however, this study narrows in on a specific group, giving focus to organic coconut cosmetic products being marketed to Thai consumers. It aims to develop an understanding of Thai consumer behavior by looking at the way in which factors such as health concern and knowledge influence purchase intention. Additionally, this study also offers recommendations about how the government and those in the agricultural industry can implement strategies to increase the market share of organic products in Thailand. Even though there is growing interest in green products among Thai consumers, consumption of organic products is still relatively low. There are, of course, many demographic variables that need to be taken into consideration when exploring the situation, including age, gender, education level, occupation, household income and marital status. Although the organic movement gained traction quite quickly in developed countries, in developing countries the response has been slower; nevertheless, receptiveness among consumers does seem to be present (Yadav \& Pathak, 2016). As information spreads, growing consumer awareness and rising health concerns are fueling the desire for organic products (Ghazali et al., 2017); however, there is still much to be learned with respect to the specific factors influencing each trend.

The coconut tree, popularly referred to as the 'tree of life', is a commercial crop grown around the world for its multipurpose "fruit". Global demand for general coconut products and coconut-based health products are expected to increase along with population growth and industrialization around the world (Alrifai \& Marcone, 2019). In their research, DebMandal \& Mandal (2011) explored the benefits coconuts, including the medicinal, nutritional and functional values various coconut-based products have to offer (e.g. coconut virgin oil, tender coconut, coconut milk, coconut leaves, and wood-based products). Coconut is a perennial plant that is widely grown in tropical countries, and of which all parts have found use in the daily life of people. It has been used for everything from the development of natural medicines for various diseases, to commercial products sold for popular consumption. Coconuts are grown for their meat, water, oil, fibers, and sugar; they are used for fuel, construction, and cosmetics, and components have even been used by the pharmaceutical industry (Batugal et al., 1998). Nutrients and microminerals from coconut water and coconut kernels are important contributors to human health and they have been shown to have antifungal, antiparasitic, hypoglycemic, antioxidant and immunostimulant properties. As Prades et al. (2016) points out, the main regions for coconut production include tropical Asian countries such as Indonesia, the Philippines, Sri Lanka, India, and Thailand.

Much literature has been written on green products, with a great deal of focus given to organic foods (e.g. Roitner-Schobesberger et al., 2008; Yazdanpanah \& Forouzani, 2015). A few studies have also been conducted with concern given to consumer purchasing behavior in relation to organic personal care products (Kim \& Chung, 2011; Ghazali et al., 2017). However, previous studies have given less attention to certain constructs which might influence the purchase intentions of customers towards organic products. Therefore, this study has extended on Ajzen's (1991) theory of planned behavior (TPB) by incorporating two additional constructs; namely, health concern and health knowledge. This study is also the first attempt to explore the influences that distinct divisions in consumers' perceived values regarding health concern and health knowledge have on purchase intention towards organic coconut cosmetic products (OCCP).

The main objective of this study is to investigate the factors that influence consumers' purchase intention towards OCCP. The study aims to identify the factors that affect Thai consumers' consumption of OCCP and develop a better understanding of related consumer behavior by extending the TPB. The study expands on previous research in the area of organic foods by exploring the role that health concerns play in motivating consumers to make organic choices. Another important contribution of this study is the focus it gives to the purchase intentions of Thai consumers. Hopes are that the knowledge gained can help stimulate related economic activity, add value to the organic crops of Thai farmers, and allow for the expansion of farming practices which are beneficial to the health of farmers and the health of the local environment. Additionally, this study will contribute to the development of strategies which will help us understand the behavior and expectations of OCCP consumers. The information can be incorporated into marketing policies adopted by governments, producers, and manufacturers operating in the Thai marketplace. In this study, 613 online questionnaires completed by respondents in Bangkok City, Thailand provided the sample data. Structural equation modeling (SEM) was employed to analyze the data with assistance of SPSS AMOS 24, which was used to test the relationships among the variables. 


\section{Literature Review}

\subsection{Review of Theoretical Models}

The Theory of Planned Behavior (TPB; Ajzen, 1991), as an expansion of the Theory of Reasoned Action (TRA; Ajzen \& Fishbein, 1988), has been extensively applied for the purpose of predicting the intentions behind human behavior (Shin et al., 2018). The TPB has been applied successfully as a tool for explanation and is widely used for predicting intentions and behaviors (Leong \& Ng, 2014). Therefore, this study aims to apply the TPB for the purpose of predicting consumer purchase intentions as they relate to OCCP. According to this model, the three constructs of attitude, subjective norm, and perceived behavioral control can be used to describe a person's intentions towards a product, a behavior, or an innovation as either positive or negative (Akbari et al., 2019).

Figure 1 illustrates the Theory of Planned Behavior (TPB).

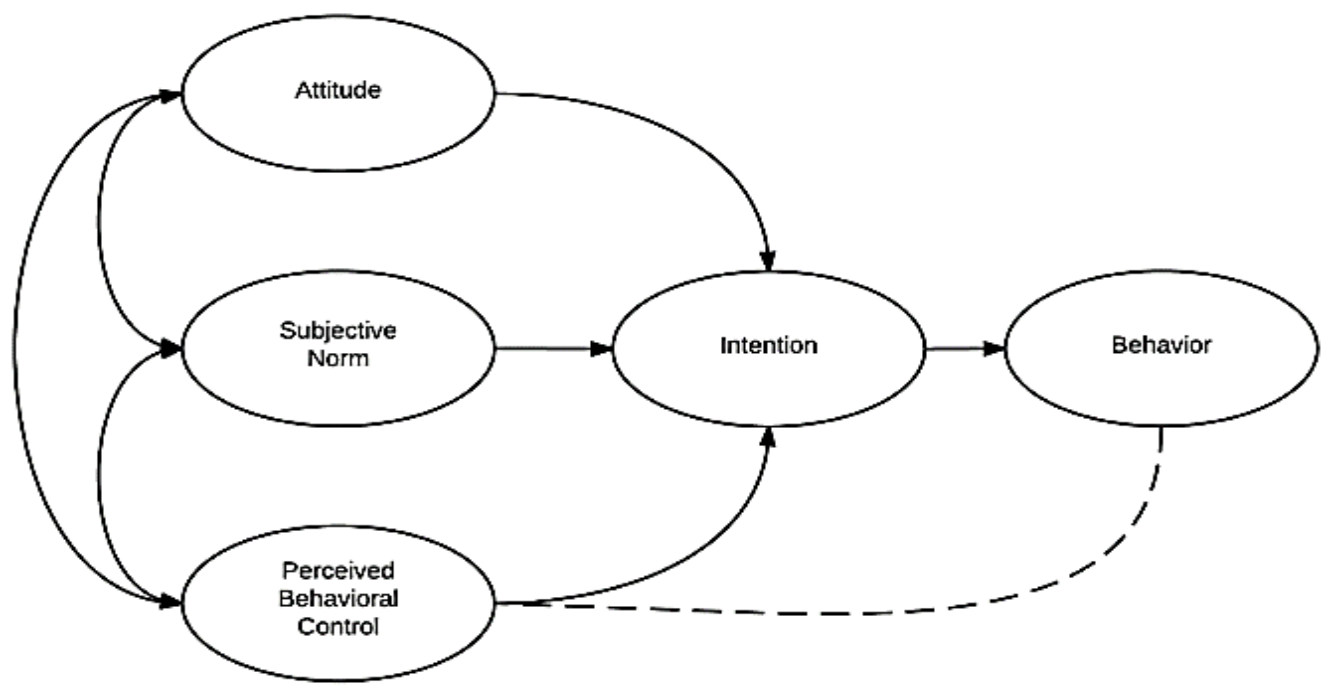

Figure 1. Theory of planned behavior model (Ajzen, 1991)

\subsubsection{Attitudes}

Attitudes refer "to the extent to which whether a person has a favorable or unfavorable evaluation of the behavior of interest" (Leong \& Ng, 2014, p. 11). The attitude construct has been shown to support intention-based correlations within the context of organic or green consumption (Ghazali et al., 2017). According to Ajzen (1991), attitudes are "likable" or "unlikable" evaluations of specific human behaviors. Attitudes are considered to be an important part of the comprehension processes consumers depend on during the purchasing process (Hill \& Lynchehaun, 2002). Chryssohoidis \& Krystallis (2005) found that literature relevant to the consumption of organic food shows that recognition of the relationship between the environment and personal health influences attitudes about purchasing organic food. Kim \& Chung (2011) also found a positive relationship between attitudes and the purchase intention towards organic skin/hair care products. Hence, based on the above, this study hypothesizes that:

$\mathbf{H}_{1}$ : Attitude is positively associated with purchase intention for OCCP.

\subsubsection{Subjective Norms}

Subjective norms refer to "the belief in which whether most people approve or disapprove of the behavior" (Leong \& Ng, 2014, p. 12). It is a motivation to exhibit a specific behavior with consideration given to the expectations of other people who are considered to be important to the actor. They could be relatives, friends, family members or other significant people in the life of the person performing the behavior. Social norms, in other words, can be defined "as the customary codes of behavior in a group of people or society" (Leong \& $\mathrm{Ng}$, 2014, p. 12). Essentially, they are sets of behavior that are standard or normative to a community of people. According to Kim \& Chung (2011), if consumers believe that it is normative to have positive thinking about organic skincare products, their intentions to purchase such products will increase.

Ajzen (1991) described subjective norms as relating to one's sense of social pressure to adopt certain behavior. Basha \& Lal (2019) noted that subjective norms had a positive influence on organic food consumption. 
Pomsanam et al. (2014) found that subjective norms play a key role in customer decisions to buy organic products in Thailand. Tarkiainen \& Sundqvist (2005) found that subjective norms also must be considered for forecasting re-purchase intentions. And finally, Kim \& Chung (2011) found that subjective norms have a significant positive relation to purchase intentions towards organic shampoo and body lotion. Hence, based on the above, this study hypothesizes that:

$\mathbf{H}_{2}$ : Subjective norms are positively associated with purchase intention for OCCP.

\subsubsection{Perceived Behavioral Control}

Perceived behavioral control (PBC) has been defined "as a person's perception of the ease or difficulty of performing the behavior of interest" (Leong \& Ng, 2014, p. 12). PBC covers the effects of such outer determinants as labeling, time, and location. All of these outer determinants might be regarded as risks or benefits, thus influencing a consumer's decision to purchase products (Chen, 2007). Kim \& Chung (2011) found that those who perceive a higher degree of individual control are inclined to engage in the behavior of consideration and have stronger behavioral motives.

Put another way, $\mathrm{PBC}$ refers "to the possession of resources, abilities and opportunities that a person believes he or she has in order to perform a particular behavior" (Ghazali et al., 2017, p. 157). Looking at attitude and perceived behavioral control, Amin et al. (2014) found a positive relationship between parental oral health knowledge on their intention to adopt certain behaviors. Madden et al. (1992) confirmed that PBC stimulates a person's behavioral motivations, as well as true behavior. Previous research has found that PBC positively influences purchase intention towards organic products (Ghazali et al., 2017). Hence, based on the above, this study hypothesized that:

$\mathbf{H}_{3}$ : Perceived behavioral control is positively associated with purchase intention towards OCCP.

\subsection{Health Concern}

Piqueras-Fiszman \& Spence (2015) maintain that health concern is an important consideration in the food consumption experience. Apaolaza et al. (2018) found a significant relationship between consumer concern for health and organic food consumption. However, individual consumer beliefs are thought to vary vastly when it comes to health and nutrition (Yarar \& Orth, 2018). Nevertheless, concerns for personal health and the health of family members were the biggest factors influencing purchasers' attitudes towards organic food (Ghazali et al., 2017). Consumers who are more health conscious have a greater propensity for their health to be positively impacted by the consumption of organic foods, which could further justify the challenges of deficient cognitive processes (Apaolaza et al., 2018).

Chrysochou \& Grunert (2014) found that health concern had an impact on the influence that organic claims had on purchase intention, as well as perceptions of the healthiness of foods. Also, organic consumers have been shown to have more concerned about their health and to develop behaviors to guard their health (Schifferstein \& Ophuis, 1998). Finlay et al. (1997) suggested that many personal health behaviors are the result of attitudes, while some are the result of subjective norms. Also, health-related behaviors can lead to changes in subjective norms or attitudes, depending on whether the behavior or goal is normatively or attitudinally controlled. Hence, based on the above, this study hypothesizes that:

$\mathbf{H}_{\mathbf{4}}$ : Health concern is positively associated with purchase intention for OCCP.

$\mathbf{H}_{5}$ : Health concern is positively associated with attitudes towards purchase intention for OCCP.

$\mathbf{H}_{6}$ : Health concern is positively associated with subjective norms towards purchase intention for OCCP.

$\mathbf{H}_{7}$ : Health concern is positively associated with perceived behavioral control towards purchase intention for OCCP.

\subsection{Health Knowledge}

The EU Health Literacy Project describes health knowledge as "the knowledge, motivation and competences to access, understand, appraise and apply health information in order to make judgments and take decisions in everyday life concerning health care, disease prevention and health promotion to maintain or improve quality of life throughout the course of life" (Sørensen et al., 2015, p. 1). Also, health knowledge refers "content and context specific knowledge about health and health care" (Gellert et al., 2016, p 2034). Quite discernable from what is popularly known about that which is defined and applied, whilst improved health outcomes and increased knowledge on preferred health options (Chin et al., 2011). Factual and procedural health knowledge are the two subdivisions for greater detail of an understanding for the knowledge on health. The two categories of health knowledge are closely related and has a dependency relationship. The knowledge on the design by 
which a health condition is treated is that of factual whilst the detailed mannerism of timing and process of executing the factual knowledge design is referred to as procedural health knowledge (Schulz et al., 2005).

Organic products are looked to as being supportive of healthy lifestyles-and health and sustainability can be explained by lifestyle (Kim \& Chung, 2011). Health knowledge is highly important when it comes to coping with and preventing chronic problems. Simply put, knowledge of health is related to health behavior (Gellert et al., 2016). Yin et al. (2010) found that health benefits, like health development and health preservation, are the dominant motivators for green consumption. Therefore, it is hypothesized that:

$\mathbf{H}_{\mathbf{8}}$ : Health knowledge is positively associated with purchase intention for OCCP.

$\mathbf{H}_{9}$ : Health knowledge is positively associated with attitudes towards purchase intention for OCCP.

$\mathbf{H}_{\mathbf{1 0}}$ : Health knowledge is positively associated with subjective norms towards purchase intention for OCCP.

$\mathbf{H}_{11}$ : Health knowledge is positively associated with perceived behavioral control towards purchasing intention for OCCP.

Organic food products can be defined as "non-chemical, pesticide-free and artificial coloring-free food products" (Leong \& Ng, 2014, p. 10). The word "organic" is a description of a process of production that does not involve chemical substances. The main determining reasons that usually lead people to consume organic products are related to concerns about personal health and the environment. This study will go into more particulars on the determinants or reason which influence consumer intention toward organic products. The conceptual framework for the hypotheses is shown in Figure 2. A total of 11 hypotheses are described according to the six constructs of attitude, subjective norms, perceived behavioral control, health concern, health knowledge, and purchase intention for OCCP.

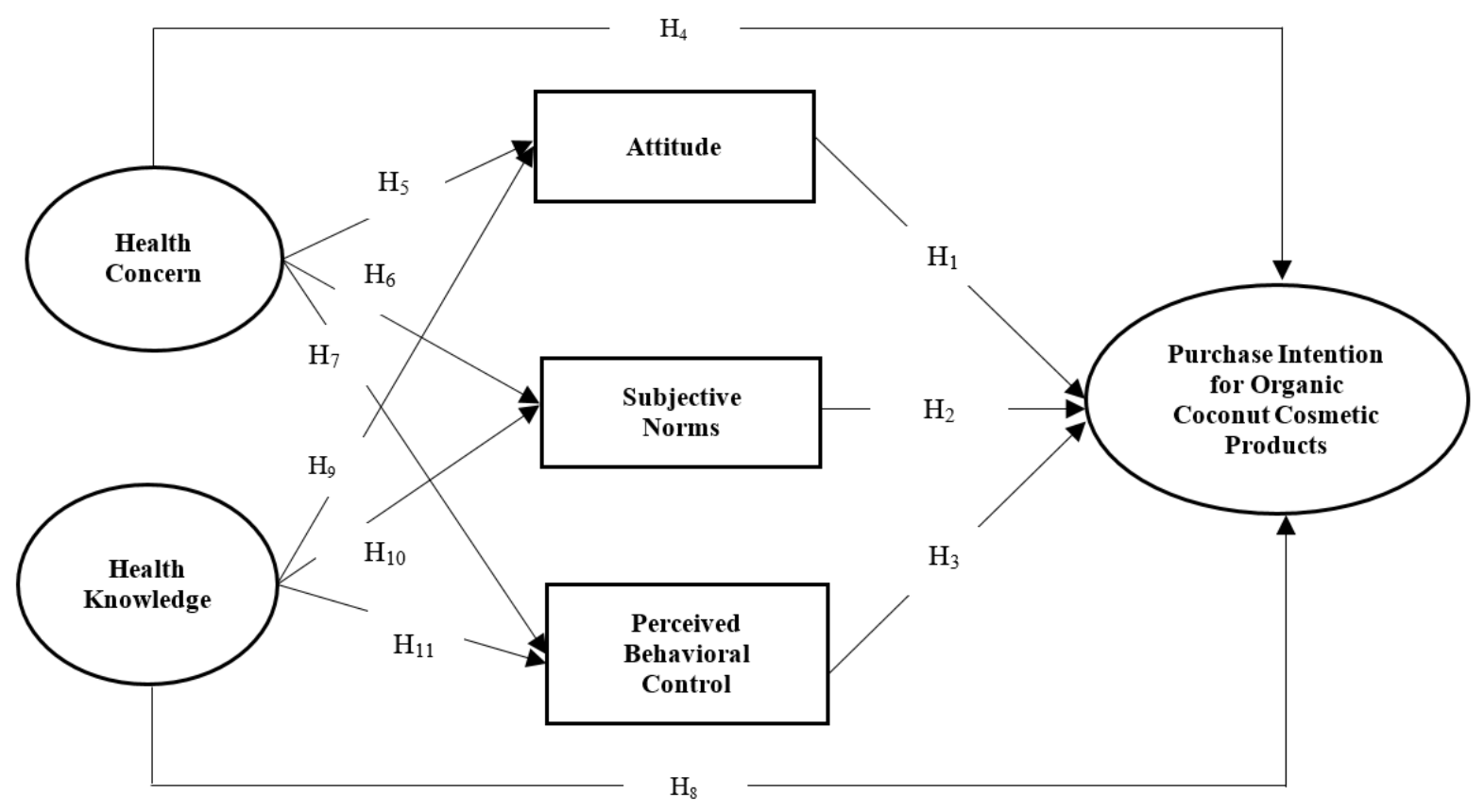

Figure 2. Hypotheses Conceptual Framework

Note. $\mathrm{H}_{1}$ : Attitude $\rightarrow$ Purchase intention for OCCP; $\mathrm{H}_{2}$ : Subjective norms $\rightarrow$ Purchase intention for OCCP; $\mathrm{H}_{3}$ : Perceived behavioral control $\rightarrow$ Purchase intention for OCCP; $\mathrm{H}_{4}$ : Health concern $\rightarrow$ Purchase intention for OCCP; $\mathrm{H}_{5}$ : Health concern $\rightarrow$ Attitude; $\mathrm{H}_{6}:$ Health concern $\rightarrow$ Subjective norms; $\mathrm{H}_{7}$ : Health concern $\rightarrow$ Perceived behavioral control; $\mathrm{H}_{8}$ : Health knowledge $\rightarrow$ Purchase intention for OCCP; $\mathrm{H}_{9}$ : Health knowledge $\rightarrow$ Attitude; $\mathrm{H}_{10}$ : Health knowledge $\rightarrow$ Subjective norms; $\mathrm{H}_{11}$ : Health knowledge $\rightarrow$ Perceived behavioral control.

\section{Methodology}

\subsection{Sample and Data Collection}

The survey issued for this study consisted of two sections that were designed to examine the following: health concern, health knowledge, attitude, subjective norms, perceived behavioral control, purchase intention for 
OCCP, and demographic characteristics of the respondents regarding consumers' intention to buy OCCP. The survey was issued online, as this allowed for the data to be collected quickly, and, in a more cost-effective manner (Klein et al., 2019). The data was collected between November, 2019 and January, 2020, during which time 613 respondents from Bangkok City, Thailand took the survey. 96 of the respondents' surveys were incomplete and thus not included in the data set. According to the rule of thumb principle, 10 cases/observations per indicator variable is considered to be the lower limit of an adequate sample size (Nunnally \& Bernstein, 1967). Therefore, based on the number of constructs, the final sample of 517 completed surveys satisfied the rule of thumb.

A quantitative non-probability sampling method was utilized with the data being collected from respondents via convenience sampling. The questionnaire was designed in English then translated to Thai, then back-translated to English to confirm that the original meaning was preserved. The target population of this study consisted of actual and potential OCCP consumers in Bangkok, the capital of Thailand. This city is generally recognized as the main economic engine of the country. The city's populace, which has the power to purchase large quantities of consumer products, has a comparably high level of consciousness towards health and organic products (Roitner-Schobesberger et al., 2008).

\subsection{Measurement}

A 7-point Likert Scale ranging from 1 (strongly disagree) to 7 (strongly agree) was used in the questionnaire. The survey issued for the data collection in this study was designed with consideration given to the six constructs included within the hypotheses. The constructs and items of measurement are shown in Table 1.

Table 1. Measurement items

\begin{tabular}{|c|c|}
\hline Constructs & Details \\
\hline $\begin{array}{l}\text { Attitude (ATT) } \\
6 \text { items } \\
\text { (Yazdanpanah \& Forouzani, 2015) }\end{array}$ & $\begin{array}{l}\text { - I think that purchasing organic coconut cosmetic products is a right thing to } \\
\text { do. } \\
\text { - I think that purchasing organic coconut cosmetic products is pleasant. } \\
\text { - I think that purchasing organic coconut cosmetic products is interesting. } \\
\text { - I think that purchasing organic coconut cosmetic products is wise. } \\
\text { - I think that purchasing organic coconut cosmetic products is undesirable. } \\
\text { - I think that purchasing organic coconut cosmetic products is not worthy. }\end{array}$ \\
\hline $\begin{array}{l}\text { Subjective Norms }(\mathbf{S N}) \\
3 \text { items } \\
\text { (Ghazali et al., 2017) }\end{array}$ & $\begin{array}{l}\text { - Most people who are important to me would think I should purchase organic } \\
\text { coconut cosmetic products. } \\
\text { - Most of my friends and important others purchase organic coconut cosmetic } \\
\text { products. } \\
\text { - Government policies and media promotion would lead me to purchase } \\
\text { organic coconut cosmetic products. }\end{array}$ \\
\hline $\begin{array}{l}\text { Perceive Behavior Control (PBC) } \\
4 \text { items } \\
\text { (Ghazali et al., 2017) }\end{array}$ & $\begin{array}{l}\text { - For me, it is easy to purchase organic coconut cosmetic products. } \\
\text { - For me, it is possible to purchase organic coconut cosmetic products. } \\
\text { - I have money to buy organic coconut cosmetic products. } \\
\text { - I myself decide to buy organic coconut cosmetic products. }\end{array}$ \\
\hline $\begin{array}{l}\text { Health Concern (HC) } \\
4 \text { items } \\
\text { (Ghazali et al., 2017) }\end{array}$ & $\begin{array}{l}\text { - I think health is very important to everyone. } \\
\text { - The human body is very delicate and can be easily damaged. } \\
\text { - I think health problems cannot be overlooked. } \\
\text { - I think we should care about our health. }\end{array}$ \\
\hline $\begin{array}{l}\text { Health Knowledge (HK) } \\
4 \text { items } \\
\text { (Yadav \& Pathak, 2016) }\end{array}$ & $\begin{array}{l}\text { - I always check the eco-label and certification before purchase organic } \\
\text { products. } \\
\text { - I know organic products are good for health. } \\
\text { - I have good health knowledge to take care my health. } \\
\text { - I know laws and regulations related to health. }\end{array}$ \\
\hline $\begin{array}{l}\text { Purchase Intention (PI) } \\
2 \text { items } \\
\text { (Yadav \& Pathak, 2016) }\end{array}$ & $\begin{array}{l}\text { - I plan to purchase organic coconut cosmetic products. } \\
\text { - I would recommend organic coconut cosmetic products to others. }\end{array}$ \\
\hline
\end{tabular}

\subsection{Data Analysis}

To examine the relationships among the variables and test the hypotheses of this study, a path analysis was conducted using structural equation modeling (SEM) with the assistance of SPSS AMOS 24. According to Jöreskog \& Sörbom (1993), SEM can specify how the hypothetical constructs are associated with the observed variables and also can estimate the unknown coefficients of the causal relationships among latent variables. This 
study followed the suggested procedure to execute the SEM data analysis and determine whether the collected data fit well with the proposed theoretical model using an SPSS version 24.0 software package.

\section{Empirical Results}

\subsection{Sample Descriptive}

The details of the respondents' demographic profiles are presented in Table 2. The results show that the sampled population was made up of $27.1 \%$ males and $72.9 \%$ females. Those who were in the $36-45$ yr. age group accounted for the largest segment, at $37.9 \%$. A little more than half of respondents were single (52.8\%). The majority of the respondents had bachelor degrees (60.5\%); and, with respect to occupation, the largest group represented in the sample were government or educational institute employees $(29.4 \%)$. Just under half of the respondents had household sizes of three members $(48.9 \%)$. And the largest segment of respondents fell into the monthly household income category of THB 50,000-59,999 (approximately 1,572-1,887 US\$) (33.5\%).

Table 2. Demographic information of this study ( $\mathrm{n}=517)$

\begin{tabular}{|c|c|c|c|}
\hline Items & Classification & Frequency & $\%$ \\
\hline \multirow{2}{*}{ Gender } & Male & 140 & 27.1 \\
\hline & Female & 377 & 72.9 \\
\hline \multirow{6}{*}{ Age } & Under 26 & 98 & 19.0 \\
\hline & $26-35$ & 111 & 21.5 \\
\hline & $36-45$ & 196 & 37.9 \\
\hline & $46-55$ & 99 & 19.1 \\
\hline & $56-65$ & 11 & 2.1 \\
\hline & Above 65 & 2 & 0.4 \\
\hline \multirow{3}{*}{ Marital Status } & Single & 273 & 52.8 \\
\hline & Married & 188 & 36.4 \\
\hline & Others & 56 & 10.8 \\
\hline \multirow{6}{*}{ Education } & Elementary school & 1 & 0.2 \\
\hline & Junior high school & 8 & 1.5 \\
\hline & Senior high school & 81 & 15.7 \\
\hline & Bachelor degree & 313 & 60.5 \\
\hline & Master degree & 107 & 20.7 \\
\hline & Ph.D. degree & 7 & 1.4 \\
\hline \multirow{8}{*}{ Occupation } & Student & 98 & 19.0 \\
\hline & Government/Educational institute & 152 & 29.4 \\
\hline & Industry & 28 & 5.4 \\
\hline & Commerce & 115 & 22.2 \\
\hline & Agriculture & 12 & 2.3 \\
\hline & Self-employed & 77 & 14.9 \\
\hline & Housewife/husband & 27 & 5.2 \\
\hline & Retired & 8 & 1.5 \\
\hline \multirow{5}{*}{ Household Size } & 1 member & 11 & 2.1 \\
\hline & 2 members & 56 & 10.8 \\
\hline & 3 members & 253 & 48.9 \\
\hline & 4 members & 145 & 28.0 \\
\hline & 5 members & 52 & 10.1 \\
\hline \multirow{10}{*}{ Household Income per monthly (THB) } & Less than THB 20,000 & 2 & 0.4 \\
\hline & THB 20,000-29,999 & 30 & 5.8 \\
\hline & THB 30,000-39,999 & 27 & 5.2 \\
\hline & THB 40,000-49,999 & 100 & 19.3 \\
\hline & THB 50,000-59,999 & 173 & 33.5 \\
\hline & THB 60,000-69,999 & 107 & 20.7 \\
\hline & THB 70,000-79,999 & 40 & 7.7 \\
\hline & THB 80,000-89,999 & 24 & 4.6 \\
\hline & ТНВ 90,000-99,999 & 10 & 1.9 \\
\hline & THB 100,000 and above & 4 & 0.8 \\
\hline
\end{tabular}

\subsection{Exploratory Factor Analysis (EFA)}

Since the measurement items for the six constructs (attitude, subjective norms, perceived behavioral control, health concern, health knowledge, purchase intention for $\mathrm{OCCP}$ ) had not been used previously for predictive purchase intention towards OCCP by Thai consumers, they were subjected to an Exploratory Factor Analysis (EFA). An EFA with Varimax rotation was executed to refine the scales by eliminating items that did not exhibit 
meaningful loads on the underlying constructs and/or did not strongly correlate with other items measuring the same construct. In order to determine if the data was suitable for EFA, the Kaiser-Myer-Olkin (KMO) measure of sampling adequacy and Bartlett's Test of Sphericity were first performed. The KMO results came in at 0.90, which is well above the recommended value of 0.40 (Kim et al., 2018). Bartlett's Test of Sphericity also turned up significant results $\left(x^{2}=7840.952, d f=253, p<.001\right)$. Based on these results, the data were considered suitable for a factor analysis. When conducting the analysis, only items with a loading greater than 0.40 on a single construct could be retained (Hair et al., 1998). Table 3 shows that the factor loadings on the intended constructs were all well above 0.6; any items with factor loadings lower than 0.6 were eliminated. That is to say, any items that failed to exhibit a substantially high loading on any factor was removed from the analysis until a clear factor structure emerged (Floyd \& Widaman, 1995). Items ATT5 and ATT6 from the attitude construct, $\mathrm{PBC} 2$ from the perceived behavioral control construct, and HK1 from the health knowledge construct were removed from the analysis due to low factor loadings (ATT5 $=-.060$, ATT6 $=-.104, \mathrm{PBC} 2=0.585$ and HK1 $=0.523$ ). The analysis revealed a six-factor solution that explains approximately $74 \%$ of the total variance.

Table 3. Exploratory factor analysis

\begin{tabular}{|c|c|c|c|c|c|c|}
\hline Constructs & 1 & 2 & 3 & 4 & 5 & 6 \\
\hline \multicolumn{7}{|l|}{ Attitude (ATT) } \\
\hline ATT1: & 0.762 & & & & & \\
\hline ATT2: & 0.740 & & & & & \\
\hline ATT3: & 0.818 & & & & & \\
\hline ATT4: & 0.784 & & & & & \\
\hline \multicolumn{7}{|l|}{ Health Concern (HC) } \\
\hline HC1: & & 0.801 & & & & \\
\hline $\mathrm{HC} 2:$ & & 0.777 & & & & \\
\hline HC3: & & 0.861 & & & & \\
\hline HC4: & & 0.830 & & & & \\
\hline \multicolumn{7}{|l|}{ Subjective Norms (SN) } \\
\hline SN1: & & & 0.719 & & & \\
\hline SN2: & & & 0.747 & & & \\
\hline SN3: & & & 0.712 & & & \\
\hline \multicolumn{7}{|c|}{ Perceived Behavioral Control (PBC) } \\
\hline PBC1: & & & & 0.684 & & \\
\hline PBC3: & & & & 0.742 & & \\
\hline PBC4: & & & & 0.818 & & \\
\hline \multicolumn{7}{|l|}{ Health Knowledge (HK) } \\
\hline HK2: & & & & & 0.627 & \\
\hline HK3: & & & & & 0.835 & \\
\hline HK4: & & & & & 0.797 & \\
\hline \multicolumn{7}{|l|}{ Purchase Intention (PI) } \\
\hline PI1: & & & & & & 0.644 \\
\hline PI2: & & & & & & 0.711 \\
\hline Variance Explained (\%) & 39.576 & 9.441 & 7.718 & 7.143 & 5.719 & 3.922 \\
\hline Cumulative $(\%)$ & 39.576 & 49.018 & 56.736 & 63.879 & 69.598 & 73.521 \\
\hline
\end{tabular}

\subsection{Measurement Model}

The descriptive statistics and constructs of the items in the questionnaire are presents in Table 4. These consist of the mean values of attitude, subjective norms, perceived behavioral control, health concern, health knowledge, and purchase intention for OCCP. The mean values range from 4.381 to 6.580 , with familiarity about laws and regulations related to health on the low end and concern about personal health on the high end. With respect to the correlation among the variables measured in this model, Table 5 shows the results, with all correlations found to be significant. The mean and standard deviations for the constructs are listed in the table. 
Table 4. Constructs and descriptive statistics of the questionnaire items

\begin{tabular}{|c|c|c|c|c|}
\hline Constructs & Indicators & Mean & Std. & Sources \\
\hline \multirow{4}{*}{ Attitude (ATT) } & ATT1 & 5.093 & 0.921 & \multirow{4}{*}{ (Yazdanpanah \& Forouzani, 2015) } \\
\hline & ATT2 & 5.104 & 0.911 & \\
\hline & ATT3 & 5.526 & 0.897 & \\
\hline & ATT4 & 5.706 & 0.939 & \\
\hline \multirow{3}{*}{ Subjective Norms (SN) } & SN1 & 4.683 & 0.992 & \multirow{3}{*}{ (Ghazali et al., 2017) } \\
\hline & SN2 & 4.598 & 0.994 & \\
\hline & SN3 & 4.656 & 1.075 & \\
\hline \multirow{3}{*}{ Perceived Behavioral Control (PBC) } & PBC1 & 4.735 & 1.020 & \multirow{3}{*}{ (Ghazali et al., 2017) } \\
\hline & PBC3 & 4.934 & 1.060 & \\
\hline & $\mathrm{PBC} 4$ & 4.547 & 1.225 & \\
\hline \multirow{4}{*}{ Health Concern (HC) } & $\mathrm{HC} 1$ & 6.279 & 0.880 & \multirow{4}{*}{ (Ghazali et al., 2017) } \\
\hline & $\mathrm{HC} 2$ & 5.853 & 0.981 & \\
\hline & $\mathrm{HC} 3$ & 6.462 & 0.805 & \\
\hline & $\mathrm{HC} 4$ & 6.580 & 0.792 & \\
\hline \multirow{3}{*}{ Health Knowledge (HK) } & HK2 & 5.882 & 0.921 & \multirow{3}{*}{ (Yadav \& Pathak, 2016) } \\
\hline & HK3 & 5.035 & 0.974 & \\
\hline & HK4 & 4.381 & 1.161 & \\
\hline \multirow{2}{*}{ Purchase Intention (PI) } & PI1 & 5.147 & 0.975 & \multirow{2}{*}{ (Yadav \& Pathak, 2016) } \\
\hline & PI2 & 5.391 & 0.901 & \\
\hline
\end{tabular}

Table 5. Correlation among variables

\begin{tabular}{lcccccccc}
\hline Constructs & Mean & Std. & ATT & SN & PBC & HC & HK & PI \\
\hline ATT & 5.357 & 0.801 & 1 & & & & & \\
SN & 4.645 & 0.875 & $0.636^{* *}$ & 1 & & & \\
PBC & 4.739 & 0.912 & $0.495^{* *}$ & $0.444^{* *}$ & 1 & & \\
HC & 6.294 & 0.741 & $0.435^{* *}$ & $0.341^{* *}$ & $0.332^{* *}$ & 1 & & \\
HK & 5.099 & 0.854 & $0.374^{* *}$ & $0.479^{* *}$ & $0.432^{* *}$ & $0.367^{* *}$ & 1 & \\
PI & 5.269 & 0.883 & $0.613^{* *}$ & $0.563^{* *}$ & $0.485^{* *}$ & $0.424^{* *}$ & $0.439^{* *}$ & 1 \\
\hline
\end{tabular}

Note. ${ }^{* *}$ Correlation is significant at the 0.01 level (two-tailed).

The values of composite reliability (CR) came in between 0.762 to 0.888 , thus exceeding the minimum suggested value of 0.70 (Fornell \& Larcker, 1981). As shown in Table 6, all of the standardized factor loading measurement results expressed values between the 0.615 and 0.925 . Thus, the factor loading values for all items were above the recommended level of 0.6 suggested by Chin et al. (1997). To measure the internal consistency among items, Cronbach's alpha ( $\alpha$ ) was used. According to Hair et al. (1998), in social psychological research, a value above 0.7 is acceptable. This study shows reasonable reliability with value ranging from 0.766 to 0.896 . Also, the average variance extracted (AVE) values came in between 0.518 to 0.744 , and were thus in-line with the recommendations of Fornell \& Larcker (1981). Table 6 presents the values for validity and reliability. 
Table 6. Reliability and validity of the constructs

\begin{tabular}{|c|c|c|c|c|c|}
\hline Constructs & Items & $\alpha$ & Factor Loading & $\mathbf{C R}$ & AVE \\
\hline \multirow{4}{*}{ Attitude (ATT) } & ATT1 & \multirow{4}{*}{0.896} & 0.815 & \multirow{4}{*}{0.888} & \multirow{4}{*}{0.664} \\
\hline & ATT2 & & 0.758 & & \\
\hline & ATT3 & & 0.861 & & \\
\hline & ATT4 & & 0.823 & & \\
\hline \multirow{3}{*}{ Subjective Norms (SN) } & SN1 & \multirow{3}{*}{0.819} & 0.848 & \multirow{3}{*}{0.819} & \multirow{3}{*}{0.604} \\
\hline & SN2 & & 0.827 & & \\
\hline & SN3 & & 0.640 & & \\
\hline \multirow{3}{*}{ Perceived Behavioral Control (PBC) } & PBC1 & \multirow{3}{*}{0.766} & 0.845 & \multirow{3}{*}{0.774} & \multirow{3}{*}{0.544} \\
\hline & PBC3 & & 0.813 & & \\
\hline & PBC4 & & 0.508 & & \\
\hline \multirow{4}{*}{ Health Concern (HC) } & $\mathrm{HC} 1$ & \multirow{4}{*}{0.875} & 0.801 & \multirow{4}{*}{0.887} & \multirow{4}{*}{0.668} \\
\hline & $\mathrm{HC} 2$ & & 0.615 & & \\
\hline & $\mathrm{HC} 3$ & & 0.925 & & \\
\hline & $\mathrm{HC} 4$ & & 0.892 & & \\
\hline \multirow{3}{*}{ Health Knowledge (HK) } & HK2 & \multirow{3}{*}{0.782} & 0.643 & \multirow{3}{*}{0.762} & \multirow{3}{*}{0.518} \\
\hline & HK3 & & 0.768 & & \\
\hline & HK4 & & 0.742 & & \\
\hline \multirow{2}{*}{ Purchase Intention (PI) } & PI1 & \multirow{2}{*}{0.869} & 0.885 & \multirow{2}{*}{0.853} & \multirow{2}{*}{0.744} \\
\hline & PI2 & & 0.839 & & \\
\hline
\end{tabular}

Note. $\boldsymbol{\alpha}$ : Cronbach's Alpha; $\boldsymbol{C R}$ : Composite Reliability; $\boldsymbol{A V E}$ : Average Variance Extracted

The results of path analysis conducted with AMOS 24.0 were used to measure the path coefficients for the relationships among the constructs in this study's model. The overall goodness-of-fit indices in the structural model were as follows: the chi-square $\left(x^{2}\right)=720.313$, degree of freedom $(d f)=141, x^{2} / d f=5.109$, the goodness-of-fit index $(\mathrm{GFI})=0.870$, Root mean square error of approximation (RMSEA) $=0.089$, Normed fit index $(\mathrm{NFI})=0.882$, Comparative fit index $(\mathrm{CFI})=0.903$, Relative fit index $(\mathrm{RFI})=0.857$, and Adjusted goodness-of-fit index $(\mathrm{AGFI})=0.825$.

Previously, MacCallum et al. (1996) elaborated on cut points and noted that RMSEA values ranging from .08 to .10 indicate a mediocre fit. According to Jöreskog \& Sörbom (1993), the GFI and AGFI indices both range from zero to 1.00 , with values close to 1.00 being indicative of a good fit. NFI, CFI, and RFI coefficient values also range from zero to 1.00 , with values close to 0.95 indicating superior fits (Hu \& Bentler, 1999). The goodness-of-fit statistics for the present study are presented in Table 7.

Table 7. Goodness-of-Fit Statistics

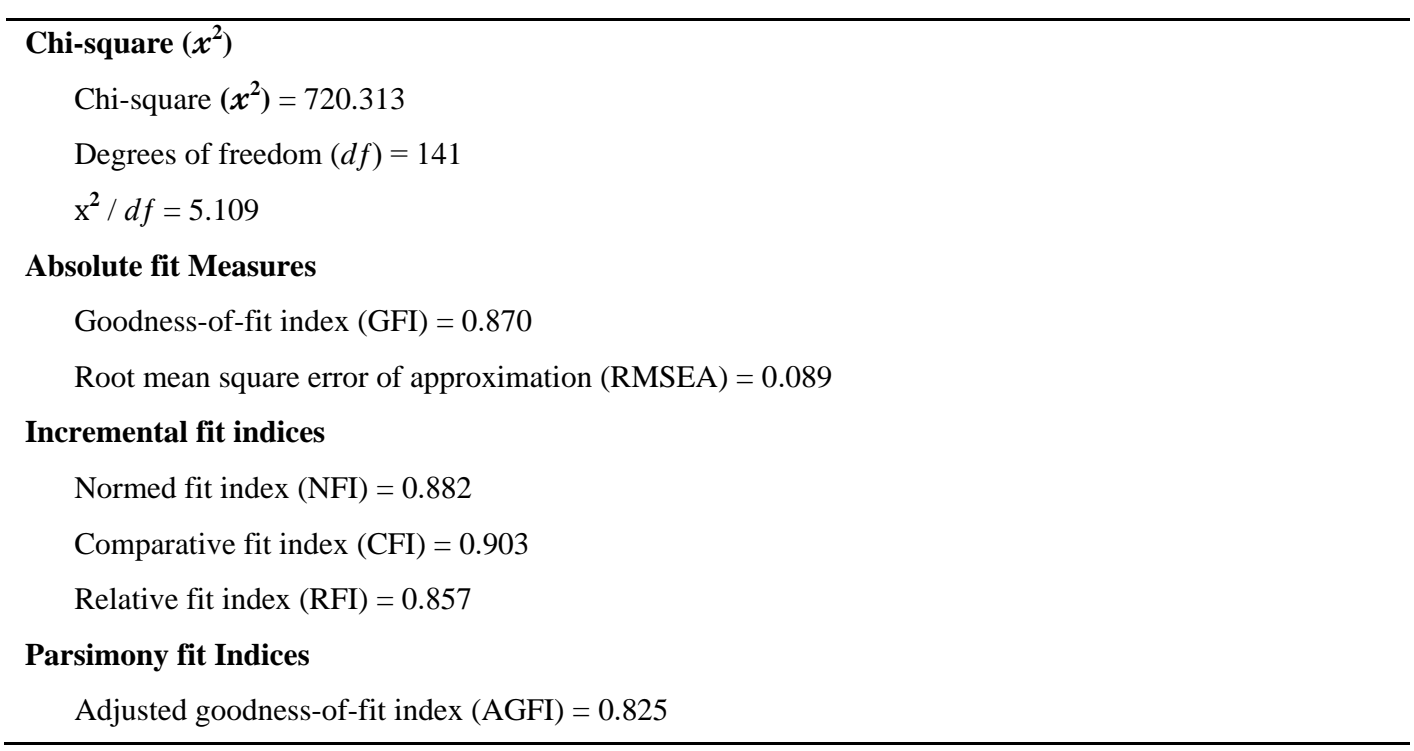




\subsection{Testing of the Structural Equation Model}

The results of the structural model and the standardized path coefficients that exist among the constructs are shown in Figure 3. As seen in Table 8 , the original theory of planned behavior variables, including attitude $\left(\mathrm{H}_{1}: \beta=\right.$ 0.377, $t=6.358, p<0.001)$, subjective norms $\left(\mathrm{H}_{2}: \beta=0.235, t=3.194, p<0.001\right)$, and perceived behavioral control $\left(\mathrm{H}_{3}: \beta=0.236, t=4.102, p<0.001\right)$, were all significant predictors of purchase intention towards OCCP. Thus, $\mathrm{H}_{1}, \mathrm{H}_{2}$, and $\mathrm{H}_{3}$ are supported. According to the data, health concern had a positive impact on purchase intention for OCCP $\left(\mathrm{H}_{4}: \beta=0.159, t=2.751, p<0.01\right)$; as did attitude $\left(\mathrm{H}_{5}: \beta=0.425, t=9.389, p<0.001\right)$, subjective norms $\left(\mathrm{H}_{6}: \beta=0.210, t=4.995, p<0.001\right)$, and perceived behavioral control $\left(\mathrm{H}_{7}: \beta=0.294, t=5.609, p<0.001\right)$. Thus, $\mathrm{H}_{4}, \mathrm{H}_{5}, \mathrm{H}_{6}$ and $\mathrm{H}_{7}$ are supported. Finally, health knowledge had a significant positive influence on attitude $\left(\mathrm{H}_{9}: \beta=0.368, t=8.771, p<0.001\right)$, subjective norms $\left(\mathrm{H}_{10}: \beta=0.495, t=9.982, p<0.001\right)$, and perceived behavioral control $\left(\mathrm{H}_{11}: \beta=0.576, t=10.486, p<0.001\right)$ meaning that $\mathrm{H}_{9}, \mathrm{H}_{10}$ and $\mathrm{H}_{11}$ are also supported. However, health knowledge did not exhibit significant influences on purchase intention for OCCP $\left(\mathrm{H}_{8}: \beta=0.086, t=\right.$ $1.109, p>0.05)$; thus, $\mathrm{H}_{8}$ is not supported.

Table 8. Hypotheses results for the structural model

\begin{tabular}{|c|c|c|c|c|c|}
\hline \multicolumn{2}{|c|}{ Hypothesized Path } & \multirow{2}{*}{$\begin{array}{c}\text { Path Estimates } \\
0.377^{* * * *}\end{array}$} & \multirow{2}{*}{$\begin{array}{c}\text { S.E. } \\
0.059\end{array}$} & \multirow{2}{*}{$\frac{t \text {-Value }}{6.358}$} & \multirow{2}{*}{$\frac{\text { Results }}{\text { Accepted }}$} \\
\hline $\mathrm{H}_{1}$ & $\mathrm{ATT} \rightarrow \mathrm{PI}$ & & & & \\
\hline $\mathbf{H}_{2}$ & $\mathrm{SN} \rightarrow \mathrm{PI}$ & $0.235^{* \cdots *}$ & 0.074 & 3.194 & Accepted \\
\hline $\mathrm{H}_{3}$ & $\mathrm{PBC} \rightarrow \mathrm{PI}$ & $0.236^{\text {**** }}$ & 0.058 & 4.102 & Accepted \\
\hline $\mathrm{H}_{4}$ & $\mathrm{HC} \rightarrow \mathrm{PI}$ & $0.159^{* * *}$ & 0.058 & 2.751 & Accepted \\
\hline $\mathrm{H}_{5}$ & $\mathrm{HC} \rightarrow \mathrm{ATT}$ & $0.425^{* \cdots *}$ & 0.045 & 9.389 & Accepted \\
\hline $\mathrm{H}_{6}$ & $\mathrm{HC} \rightarrow \mathrm{SN}$ & $0.210^{* * * *}$ & 0.042 & 4.995 & Accepted \\
\hline $\mathrm{H}_{7}$ & $\mathrm{HC} \rightarrow \mathrm{PBC}$ & $0.294^{* * * *}$ & 0.052 & 5.609 & Accepted \\
\hline $\mathrm{H}_{8}$ & $\mathrm{HK} \rightarrow \mathrm{PI}$ & 0.086 & 0.078 & 1.109 & Rejected \\
\hline $\mathbf{H}_{9}$ & $\mathrm{HK} \rightarrow \mathrm{ATT}$ & $0.368^{* * * *}$ & 0.042 & 8.771 & Accepted \\
\hline $\mathrm{H}_{10}$ & $\mathrm{HK} \rightarrow \mathrm{SN}$ & $0.495^{* * *}$ & 0.050 & 9.982 & Accepted \\
\hline $\mathrm{H}_{11}$ & $\mathrm{HK} \rightarrow \mathrm{PBC}$ & $0.576^{* \cdots *}$ & 0.055 & 10.486 & Accepted \\
\hline
\end{tabular}

Note. ${ }^{*} p<0.05,{ }^{* *} p<0.01,{ }^{* * *} p<0.001$.

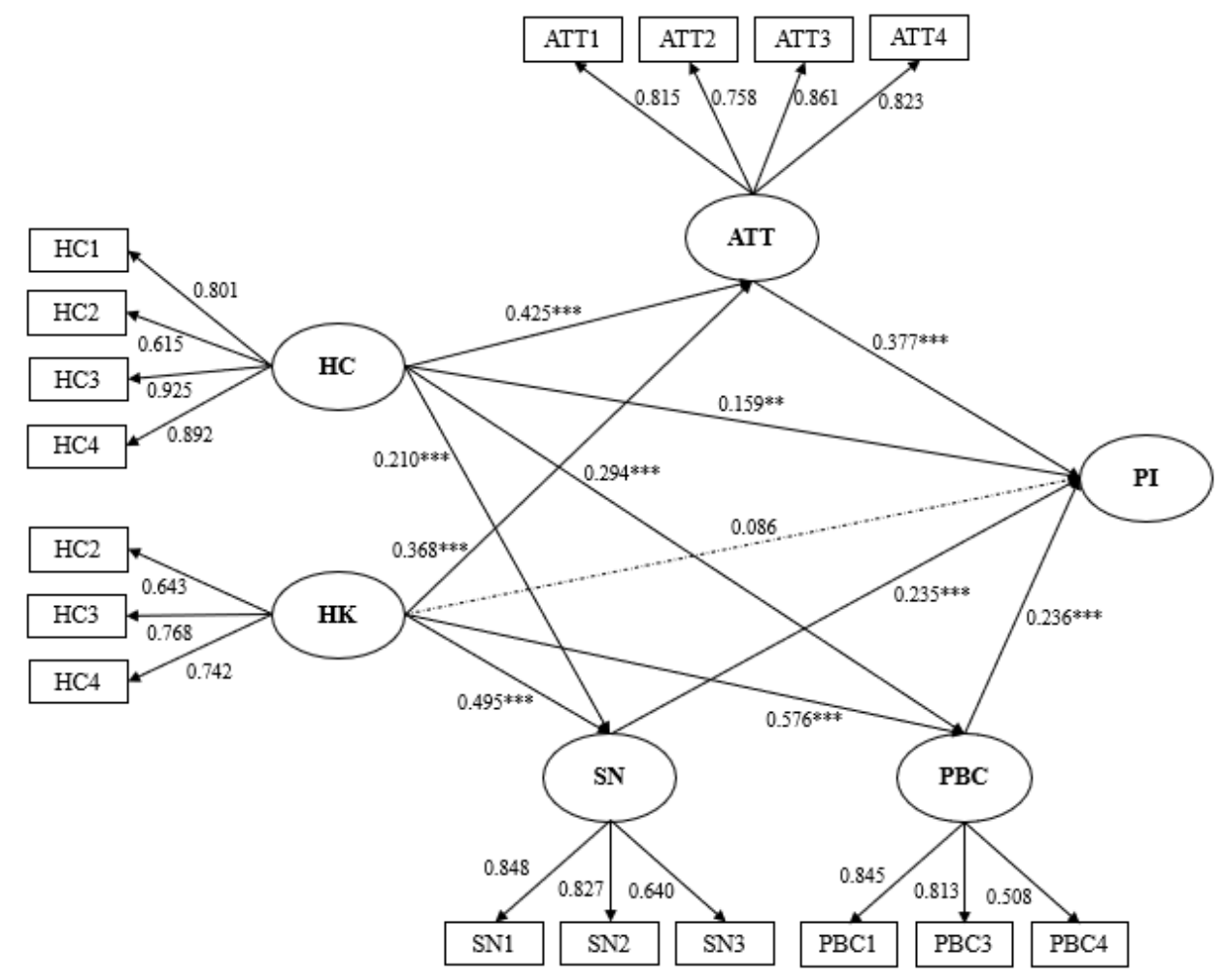

Figure 3. The construct research model results

(Note. $* \mathrm{p}<0.05, * * \mathrm{p}<0.01, * * * \mathrm{p}<0.001$ ) 


\section{Discussions}

The results of the study indicate that consumers of OCCP in Bangkok are inclined to be over 35 years in age, have academic degrees and relatively high household income levels; however, younger consumers (less than 26 years old) also seem to have high purchase intentions towards OCCP. The results here are consistent with another study in Bangkok which found that general organic buyers also have higher income levels and higher levels of education (Roitner-Schobesberger et al., 2008). Also, consistent with Aguirre's (2007) research, in Bangkok, females are more likely to buy organic products than males.

The various constructs within the TPB, including attitude, subjective norms and perceived behavioral control, were found to have a significant positive impact on purchase intention for OCCP. Attitude was found to have the most significant positive effect on consumers purchase intention, meaning that attitude is a strong predictor of purchase intention for OCCP. This is followed by perceived behavioral control and, lastly, subjective norms. The results agree with the attitude behavior theory of Ajzen (1991) and later studies, such as Maichum et al. (2018), who stated that attitude towards organic products had a positive and relatively strong correlation with organic consumption. Conversely, Shin et al. (2018) who found attitude and subjective norms to be concerned with self-interest motives suggested that perceived behavioral control is a more significant factor when it comes to influencing a person's intention to selected organic items based on social motives. The findings show that based on the TPB model, subjective norms have the lowest influence on purchase intention for OCCP when compared with the other constructs of attitude and perceived behavioral control. According to Chan \& Lau (2002), subjective norms show that influence from family members' or friends resulted in a little impulsion concerning the reasons to purchase organic products for consumers. In his TPB model, Ajzen (1991) understood behavioral control to have a positive effect and direct influence on intention and behavior. The present study has shown that the influence of perceived behavioral control is smaller than attitude but greater than subjective norms.

Health concern was found to be a significant positive factor when it came to influencing attitude, subjective norms, perceived behavioral control, and purchase intention for organic coconut cosmetic products, thus confirming four of this study's hypotheses $\left(\mathrm{H}_{4}, \mathrm{H}_{5}, \mathrm{H}_{6}\right.$, and $\left.\mathrm{H}_{7}\right)$. According to Srinieng \& Thapa (2018), most people in Thailand are aware of some household members with ailing health and would attempt to find knowledge on the health and environmental effects of organic produce. The previous research findings on organic foods showed that concerns about product safety, personal health, and environmental friendliness are important motivators for decisions on organic consumption (Bauer et al., 2013). Conversely, Sun (2008) found that health does not play an imminent role in increasing the level of awareness of such issues. Results are consistent with a priori literature from Apaolaza et al. (2018), which highlights the consumption of organic food as more beneficial to the health of the consumers. The satisfaction derived from less concerns of ill health is a direct effect of the belief that significant nutrients are gained from healthy diets such as an organic diet.

In the present study, health knowledge was found to have significant and positive influences on attitude, subjective norms, and perceived behavioral control, as hypothesized in $\mathrm{H}_{9}, \mathrm{H}_{10}$, and $\mathrm{H}_{11}$. This concurs with von Wagner et al. (2009), who found that health knowledge is related to health behavior. Beier \& Ackerman (2003) identified influences of health knowledge factors across a wide scope of situations including mental health, nutrition, aging, and illness. In the present study, however, contrary to hypothesis $8\left(\mathrm{H}_{8}\right)$, health knowledge did not have a significant effect on purchase intention for OCCP. According to Yarar \& Orth (2018), the concept of healthy nutrition commonly impacts the life of consumers as key decisions are made for personal goals, moral aspects of consumption and production, and eating restrictions. Additionally, the source for nutrition and health information is generally persons of trust, such as family and friends. Roitner-Schobesberger et al. (2008) found that among Thai consumers, few had familiar understandings of organic food. Confusion among consumers and lack of knowledge and trust in Thai organic certifications and controls are indeed barriers for Thai consumers (Nuttavuthisit \& Thøgersen, 2017).

As predicted in $\mathrm{H}_{1}, \mathrm{H}_{2}$, and $\mathrm{H}_{3}$, the study's findings confirmed that attitude, subjective norms, and perceived behavioral control do influence purchase intention for OCCP. That is to say, those who have favorable attitudes, or consider it to be efficacious to choose organic products, are more likely to choose OCCP. However, Ghazali et al. (2017) found that, generally, decisions to purchase organic products are driven by personal determinants and interests rather than those of peers, reference groups, and family members. For example, individuals will give consideration to their own skin type, allergic reactions to certain ingredients, and preferences for various product attributes such as scent, or whitening, soothing, and/or hydrating properties. In Bangkok, as this study confirms, based on the TPB, health concern and health knowledge aspects are closely associated with consumers' intention to purchase organic products. 


\section{Conclusions}

This study extended on the TPB model to investigate factors affecting consumer behavior and the consumption of OCCP among Thai consumers. Health concern and health knowledge were added to the constructs of attitude, subjective norms and perceived behavioral control in the original TPB framework. The results show that SEM can predict the variability of the intention and were significant predictors of consumer purchase intention. The study offers an integration of its research findings and provides suggestions for future studies on consumer OCCP purchase behavior. Based on the TPB, this research provides valuable insight into the important role that attitude plays in predicting intention to purchase OCCP when compared with subjective norms and perceived behavioral control. Additionally, the determinant of health concern was shown to have a significant positive influence on the purchase intentions of consumers towards OCCP. The study thus confirmed that health concern is becoming an increasingly important factor for Thai consumers. Health knowledge, on the other hand, was not shown to influence consumer purchase intention, suggesting that Thai consumers are not familiar with the related laws and regulations. This study provides producers and marketers with a better understanding of consumer purchase behavior and consumer perception so that they will be in a better position to capitalize on the growing interest in various organic products. Based on the findings, producers should be able to develop more effective marketing activities by giving focus to health benefits and safety factors.

This study supports the Thai government policy to develop an agriculture system based on sustainable management and efficient use of agriculture resources and infrastructure, while also providing Thai farmers with the ability to use production resources such as land, soil, and water properly and suitably to help biodiversity and to expand the market for organic products. This study provides evidence regarding consumers' underlying motivations to buy OCCP, which should play a defining role in the organic coconut cosmetic market in Thailand. It presents an opportunity for organic coconut producers in Thailand to employ growth strategies and gain greater market share. It maintains that such factors as health concern and knowledge can increase the predictive power of TPB for purchase intention towards OCCP. By getting a clearer look at potential consumers, the organic coconut cosmetic producers will be better equipped to develop effective marketing strategies.

This study explored issues which have never been studied in Thailand, addressing questions that are important to governmental and non-governmental organizations and organic coconut producers. The information can be used to create strategies to help with growth and acquisition of greater market share. Specifically, in order to promote OCCP consumption, the government has to promote and support the establishment of knowledge and understanding about the difference between OCCP and chemical cosmetic products. It is important for the government to work closely together with the producers, not only to diminish consumer concern about those products, but also to help transform perceived demand into actual demand for OCCP. Furthermore, since issues related to health knowledge did not influence consumers purchase intention towards OCCP, policymakers and producers could try to develop consumer health knowledge related to organic products to thereby hopefully encourage more consumers to purchase organic products. Second, on the marketing end, due to high prices and limited variety of OCCP on markets, such products have not been fully embraced by local consumers. Thus, the government and related sectors should work to establish understanding of OCCP among consumers and provide more market channels to increase visibility and distribution of organic products. Finally, by using such tools as TPB to predict consumer purchase intention towards OCCP, producers can have more confidence in their OCCP investments, knowing that as consumer trust in the health and safety of OCCP increases, future consumption will also increase.

Regarding the limitations and directions of the present study, to begin with, since consumers of organic products generally live in urban areas, the targeted sample consisted of residents of Bangkok rather than those in other places in the country. Thus, future research could collect data from other areas to get an understanding of trends and patterns on a broader scale. People's values, social norms, and motivations for consuming organic products may differ in different cultural contexts, as perceptions and needs are dependent on a large number of circumstances. However, this study applied convenience sampling method where the researcher selected the research sample based on the ease and proximity to the researcher. In future investigations into consumer purchase intention towards other organic products, such as ginger, durian, tamarind or other agricultural products unique to Thailand could also be carried out. Future research could also look to examine consumers' intentions to re-purchase OCCP based on other factors, such as product knowledge, hedonic value, safety value, etc.

\section{Acknowledgements}

We would like to thank our respondents for spending their time to answer the questionnaire and the reviewers of this paper for their valuable comments. 


\section{References}

Aguirre, J. A. (2007). The farmer's market organic consumer of Costa Rica. British Food Journal, 109(2), 145-154. https://doi.org/10.1108/00070700710725509

Ajzen, I. (1991). The theory of planned behavior. Organizational Behavior and Human Decision Processes, 50(2), 179-211. https://doi.org/10.1016/0749-5978(91)90020-T

Ajzen, I., \& Fishbein, M. (1988). Theory of reasoned action-Theory of planned behavior. University of South Florida, 2007, 67-98.

Akbari, M., Fozouni Ardekani, Z., Pino, G., \& Maleksaeidi, H. (2019). An extended model of Theory of Planned Behavior to investigate highly-educated iranian consumers' intentions towards consuming genetically modified foods. Journal of Cleaner Production, 227, 784-793. https://doi.org/10.1016/j.jclepro.2019.04.246

Akenji, L. (2014). Consumer scapegoatism and limits to green consumerism. Journal of Cleaner Production, 63, 13-23. https://doi.org/10.1016/j.jclepro.2013.05.022

Alrifai, O., \& Marcone, M. F. (2019). Coconut-The Tree of Life-Improvement by Biotechnology. Comprehensive Biotechnology (Third Edition), 4, 586-594.

Amin, M., Nyachhyon, P., Elyasi, M., \& Al-Nuaimi, M. (2014). Impact of an Oral Health Education Workshop on Parents' Oral Health Knowledge, Attitude, and Perceived Behavioral Control among African Immigrants. Journal of Oral Diseases, 2014, 1-7. https://doi.org/10.1155/2014/986745

Apaolaza, V., Hartmann, P., D'Souza, C., \& López, C. M. (2018). Eat organic - Feel good? The relationship between organic food consumption, health concern and subjective wellbeing. Food Quality and Preference, 63, 51-62. https://doi.org/10.1016/j.foodqual.2017.07.011

Basha, M. B., \& Lal, D. (2019). Indian consumers' attitudes towards purchasing organically produced foods: An empirical study. Journal of Cleaner Production, 215, 99-111. https://doi.org/10.1016/j.jclepro.2018.12.098

Batugal, P. A., Ramanatha Rao, V., \& Bong, C. (1998). Promoting multi-purpose uses and competitiveness of the coconut. Proceedings of a workshop September 1996, Chumphon, Thailand. 26-29.

Bauer, H. H., Heinrich, D., \& Schäfer, D. B. (2013). The effects of organic labels on global, local, and private brands. Journal of Business Research, 66(8), 1035-1043. https://doi.org/10.1016/j.jbusres.2011.12.028

Beier, M. E., \& Ackerman, P. L. (2003). Determinants of health knowledge: an investigation of age, gender, abilities, personality, and interests. Journal of Personality and Social Psychology, 84(2), 439-448. https://doi.org/10.1037/0022-3514.84.2.439

Chan, R. Y. K., \& Lau, L. B. Y. (2002). Explaining Green Purchasing Behavior. Journal of International Consumer Marketing, 14(2-3), 9-40. https://doi.org/10.1300/J046v14n02_02

Chen, M. F. (2007). Consumer attitudes and purchase intentions in relation to organic foods in Taiwan: Moderating effects of food-related personality traits. Food Quality and Preference, 18(7), 1008-1021. https://doi.org/10.1016/j.foodqual.2007.04.004

Chin, J., Morrow, D. G., Stine-Morrow, E. A., Conner-Garcia, T., Graumlich, J. F., \& Murray, M. D. (2011). The process-knowledge model of health literacy: evidence from a componential analysis of two commonly used measures. Journal of Health Communication, 16(3), 222-241. https://doi.org/10.1080/10810730.2011.604702

Chin, W. W., Gopal, A., \& Salisbury, W. D. (1997). Advancing the theory of adaptive structuration: The development of a scale to measure faithfulness of appropriation. Information Systems Research, 8(4), 342-367. https://doi.org/10.1287/isre.8.4.342

Chrysochou, P., \& Grunert, K. G. (2014). Health-related ad information and health motivation effects on product evaluations. Journal of Business Research, 67(6), 1209-1217. https://doi.org/10.1016/j.jbusres.2013.05.001

Chryssohoidis, G. M., \& Krystallis, A. (2005). Organic consumers' personal values research: Testing and validating the list of values (LOV) scale and implementing a value-based segmentation task. Food Quality and Preference, 16(7), 585-599. https://doi.org/10.1016/j.foodqual.2005.01.003

DebMandal, M., \& Mandal, S. (2011). Coconut (Cocos nucifera L.: Arecaceae): In health promotion and disease prevention. Asian Pacific Journal of Tropical Medicine, 4(3), 241-247.

https://doi.org/10.1016/S1995-7645(11)60078-3 
D'Souza, C., \& Taghian, M. (2005). Green advertising effects on attitude and choice of advertising themes. Asia Pacific Journal of Marketing and Logistics, 17(4), 51-66. https://doi.org/10.1108/13555850510672386

Finlay, K. A., Trafimow, D., \& Jones, D. (1997). Predicting health behaviors from attitudes and subjective norms: Between-subjects and within-subjects analyses. Journal of Applied Social Psychology, 27(22), 2015-2031. https://doi.org/10.1111/j.1559-1816.1997.tb01638.x

Floyd, F. J., \& Widaman, K. F. (1995). Factor analysis in the development and refinement of clinical assessment instruments. Psychological Assessment, 7(3), 286-299. https://doi.org/10.1037/1040-3590.7.3.286

Fornell, C., \& Larcker, D. F. (1981). Evaluating structural equation models with unobservable variables and measurement error. Journal of Marketing Research, 18(1), 39-50. https://doi.org/10.1177/002224378101800104

Gellert, P., Detel, S., Ernsting, C., \& Oedekoven, M. (2016). Development and psychometric properties of a health knowledge test on six chronic conditions. Patient Education and Counseling, 99(12), 2034-2042. https://doi.org/10.1016/j.pec.2016.07.035

Ghazali, E., Soon, P. C., Mutum, D. S., \& Nguyen, B. (2017). Health and cosmetics: Investigating consumers' values for buying organic personal care products. Journal of Retailing and Consumer Services, 39, 154-163. https://doi.org/10.1016/j.jretconser.2017.08.002

Hair, J. F., Black, W. C., Babin, B. J., Anderson, R. E., \& Tatham, R. L. (1998). Multivariate data analysis (Vol. 5): Prentice hall Upper Saddle River, NJ.

Hill, H., \& Lynchehaun, F. (2002). Organic milk: attitudes and consumption patterns. British Food Journal, 104(7), 526-542. https://doi.org/10.1108/00070700210434570

Hu, L. T., \& Bentler, P. M. (1999). Cutoff criteria for fit indexes in covariance structure analysis: Conventional criteria versus new alternatives. Structural Equation Modeling: A Multidisciplinary Journal, 6(1), 1-55. https://doi.org/10.1080/10705519909540118

Jörreskog, K. G., \& Sörbom, D. (1993). Structural equation modelling with the simplis command language. Scientific Software International Inc., Lincolnwood, IL, 60712-61704.

Kim, H. Y., \& Chung, J. E. (2011). Consumer purchase intention for organic personal care products. Journal of Consumer Marketing, 28(1), 40-47. https://doi.org/10.1108/07363761111101930

Kim, S., Kandampully, J., \& Bilgihan, A. (2018). The influence of eWOM communications: An application of online social network framework. Computers in Human Behavior, 80, 243-254. https://doi.org/10.1016/j.chb.2017.11.015

Kim, Y. J., Njite, D., \& Hancer, M. (2013). Anticipated emotion in consumers' intentions to select eco-friendly restaurants: Augmenting the theory of planned behavior. International Journal of Hospitality Management, 34, 255-262. https://doi.org/10.1016/j.ijhm.2013.04.004

Kirk, D. (1995). Environmental management in hotels. International Journal of Contemporary Hospitality Management, 7(6), 3-8. https://doi.org/10.1108/09596119510095325

Klein, F., Emberger-Klein, A., Menrad, K., Möhring, W., \& Blesin, J.-M. (2019). Influencing factors for the purchase intention of consumers choosing bioplastic products in Germany. Sustainable Production and Consumption, 19, 33-43. https://doi.org/10.1016/j.spc.2019.01.004

Laroche, M., Bergeron, J., \& Barbaro-Forleo, G. (2001). Targeting consumers who are willing to pay more for environmentally friendly products. Journal of Consumer Marketing, 18(6), 503-520. https://doi.org/10.1108/EUM0000000006155

Leong, G. Y., \& Ng, Y. L. (2014). The factors influence consumer behaviour on the purchase of organic products. (Unpublished doctoral dissertation). Universiti Tunku Abdul Rahman (UTAR), Kuala Lumpur, Malaysia.

MacCallum, R. C., Browne, M. W., \& Sugawara, H. M. (1996). Power analysis and determination of sample size for covariance structure modeling. Psychological Methods, 1(2), 130-149.

https://doi.org/10.1037/1082-989X.1.2.130

Madden, T. J., Ellen, P. S., \& Ajzen, I. (1992). A comparison of the theory of planned behavior and the theory of reasoned action. Personality and Social Psychology Bulletin, 18(1), 3-9.

https://doi.org/10.1177/0146167292181001 
Maichum, K., Parichatnon, S., \& Peng, K. C. (2016). Application of the Extended Theory of Planned Behavior Model to Investigate Purchase Intention of Green Products among Thai Consumers. Sustainability, 8(10), 1-20. https://doi.org/10.3390/su8101077

Nunnally, J. C., \& Bernstein, I. H. (1967). McGraw-Hill series in psychology. Psychometric theory. New York, NY, US: McGraw-Hill.

Nuttavuthisit, K., \& Thøgersen, J. (2015). The Importance of Consumer Trust for the Emergence of a Market for Green Products: The Case of Organic Food. Journal of Business Ethics, 140(2), 323-337. https://doi.org/10.1007/s10551-015-2690-5

Piqueras-Fiszman, B., \& Spence, C. (2015). Sensory expectations based on product-extrinsic food cues: An interdisciplinary review of the empirical evidence and theoretical accounts. Food Quality and Preference, 40, 165-179. https://doi.org/10.1016/j.foodqual.2014.09.013

Pomsanam, P., Napompech, K., \& Suwanmaneepong, S. (2014). Factors driving Thai consumers' intention to purchase organic foods. Asian Journal of Scientific Research, 7(4), 434-446. https://doi.org/10.3923/ajsr.2014.434.446

Prades, A., Salum, U. N., \& Pioch, D. (2016). New era for the coconut sector. What prospects for research? $O C L$, 23(6), 1-4. https://doi.org/10.1051/ocl/2016048

Roitner-Schobesberger, B., Darnhofer, I., Somsook, S., \& Vogl, C. R. (2008). Consumer perceptions of organic foods in Bangkok, Thailand. Food Policy, 33(2), 112-121. https://doi.org/10.1016/j.foodpol.2007.09.004

Schifferstein, H. N., \& Ophuis, P. A. O. (1998). Health-related determinants of organic food consumption in the Netherlands. Food Quality and Preference, 9(3), 119-133. https://doi.org/10.1016/S0950-3293(97)00044-X

Schulz, P. J., \& Nakamoto, K. (2005). Emerging themes in health literacy. Studies in Communication Science, $5(2), 1-10$.

Shin, Y. H., Im, J., Jung, S. E., \& Severt, K. (2018). The theory of planned behavior and the norm activation model approach to consumer behavior regarding organic menus. International Journal of Hospitality Management, 69, 21-29. https://doi.org/10.1016/j.ijhm.2017.10.011

Sørensen, K., Pelikan, J. M., Röthlin, F., Ganahl, K., Slonska, Z., Doyle, G., ... Consortium, H.-E. (2015). Health literacy in Europe: comparative results of the European health literacy survey (HLS-EU). European Journal of Public Health, 25(6), 1053-1058. https://doi.org/10.1093/eurpub/ckv043

Srinieng, S., \& Thapa, G. B. (2018). Consumers' Perception of Envirionmental and Health Benefits, and Consumption of Organic Vegetable in Bangkok. Agriculture and Food Economics, 6(1), 1-17. https://doi.org/10.1186/s40100-018-0100-x

Sun, Y. H. (2008). Health concern, food choice motives, and attitudes toward healthy eating: the mediating role of food choice motives. Appetite, 51(1), 42-49. https://doi.org/10.1016/j.appet.2007.11.004

Tarkiainen, A., \& Sundqvist, S. (2005). Subjective norms, attitudes and intentions of Finnish consumers in buying organic food. British Food Journal, 107(11), 808-822. https://doi.org/10.1108/00070700510629760

Ueasangkomsate, P., \& Santiteerakul, S. (2016). A Study of Consumers' Attitudes and Intention to Buy Organic Foods for Sustainability. Procedia Environmental Sciences, 34, 423-430. https://doi.org/10.1016/j.proenv.2016.04.037

von Wagner, C., Steptoe, A., Wolf, M. S., \& Wardle, J. (2009). Health literacy and health actions: a review and a framework from health psychology. Health Education and Behavior, 36(5), 860-877. https://doi.org/10.1177/1090198108322819

Willer, H., \& Lernoud, J. (2019). The world of organic agriculture. Statistics and emerging trends 2019: Research Institute of Organic Agriculture FiBL and IFOAM Organics International.

Yadav, R., \& Pathak, G. S. (2016). Young consumers' intention towards buying green products in a developing nation: Extending the theory of planned behavior. Journal of Cleaner Production, 135, 732-739. https://doi.org/10.1016/j.jclepro.2016.06.120

Yarar, N., \& Orth, U. R. (2018). Consumer lay theories on healthy nutrition: A Q methodology application in Germany. Appetite, 120, 145-157. https://doi.org/10.1016/j.appet.2017.08.026 
Yazdanpanah, M., \& Forouzani, M. (2015). Application of the Theory of Planned Behaviour to predict Iranian students' intention to purchase organic food. Journal of Cleaner Production, 107, 342-352. https://doi.org/10.1016/j.jclepro.2015.02.071

Yin, S., Wu, L., Du, L., \& Chen, M. (2010). Consumers' purchase intention of organic food in China. Journal of the Science of Food and Agriculture, 90(8), 1361-1367. https://doi.org/10.1002/jsfa.3936

\section{Copyrights}

Copyright for this article is retained by the author(s), with first publication rights granted to the journal.

This is an open-access article distributed under the terms and conditions of the Creative Commons Attribution license (http://creativecommons.org/licenses/by/4.0/). 